\author{
Beata ROGOWSKA-RAJDA, PhD \\ Faculty of Economic Sciences, University of Warsaw \\ e-mail: brogowska@wne.uw.edu.pl \\ ORCID: 0000-0003-3879-3440
}

DOI: $10.15290 /$ oes.2020.03.101.05

\title{
INSTITUTION OF VAT BINDING RATE INFORMATION - THEORETICAL AND PRACTICAL ASPECTS ${ }^{1}$
}

\begin{abstract}
Summary
Purpose - The purpose of the article is to provide a comprehensive analysis of the new institution, i.e. the Binding Rate Information, in theoretical and practical terms. Therefore, the nature of this institution and its impact on business finances will be examined. This article also aims to verify the degree of its use by entrepreneurs and indicate possible directions of future changes.

Research method - Literature reviews, analysis of legal acts, analysis of the decisions issued by administrative courts and the CJEU, and analysis of statistical data which relates to Binding Rate Information were used as part of this research.

Research description - The analysis includes legal regulations concerning VAT rates and their impact on enterprises; also statistical data processed by the National Revenue Information System (KIS) in respect of Binding Rate Information issued.

Results - Binding Rate Information reduces the tax risk of entrepreneurs related to the application of VAT rates. For this reason, entrepreneurs are willing to take advantage of this institution. However, this institution may have a negative impact on the finances of enterprises by distorting their competitiveness on the market in case of differences in the judicial decisions issued on rates classification. Consequently, it is crucial to maintain uniformity in the issued decisions. Despite the positive assessment of the new institution, it is necessary to consider to set it in a specific timeframe, and to limit the legal protection guaranteed by this institution in certain situations. It is recommended that further analysis should be undertaken with respect to extending the scope of binding information to include VAT exemptions.
\end{abstract}

Keywords: VAT, Binding Rate Information, VAT rates, corporate finance

JEL Classification: H25, H26, H32

\section{Introduction}

The Polish model of VAT rates ${ }^{2}$ does not differ from the models applied in the majority of the EU states with respect to the number of reduced rates; however,

1 Article received on 5 May 2020, accepted on 10 June 2020.

${ }^{2}$ Goods and services tax are the Polish version of value added tax. For the purpose of this paper, these terms shall be used interchangeably. 
it varies from the majority of the EU states with respect to the application of those rates as in Poland this system is more extensively applied than in other countries. The level of complexity of tax regulations in this area raises challenges for companies in their proper reading and application. Different VAT rates complicate the accounting system within an organisation, lead to classification problems and increase the cost of tax compliance. Difficulties in assigning the appropriate VAT rate by businesses translate into negative effects on their finances. The aim of the shielding action in 2019 was to introduce into the Polish tax system the possibility for taxpayers to ask tax authorities for a Binding Rate Information (WIS). Its purpose is to reduce the costs of compliance with tax obligations and the tax risk. The subject of this paper is to assess the extent to which entrepreneurs employ the institution of Binding Rate Information and to diagnose its impact on the finances of enterprises in theoretical and practical terms.

\section{VAT rates system in Poland}

VAT rates in Poland are determined by the frames set by the Directive [Dyrektywa, 2006]. The basic rate adopted by a European Union Member State may not be lower than 15\%. Member States may apply one or two reduced rates, but the reduced rates may not be less than 5\%. Reduced rates may be applied to goods and services listed in Annex III to the Directive, however for certain Member States the Directive provides for exceptions for strictly defined goods and services. When applying reduced rates to specific categories of goods, Member States may use the Combined Nomenclature $(\mathrm{CN})$ to determine the precise scope of the specific category. Standard rates in the European Union range from 17\% to 27\% (or 10 percentage points) while reduced rates range from $5 \%$ to $18 \%$ (13 percentage points).

Currently, Poland has three VAT rates of $5 \%, 8 \%$ and $23 \%$, as per the structure of the EU regulations. The $0 \%$ rate adopted in the Polish nomenclature corresponds to the EU exemption category with the right to deduct. Only 6 Member States have a standard rate higher than $23 \%$, while 19 countries have a standard rate lower than $23 \%$. However, it should be emphasised that Poland applies reduced rates in a very wide range, which is one of the largest of all the EU countries. Consequently, the weighted average VAT rate in Poland is $16.9637 \%{ }^{3}$. The ratio of the average VAT rate to the standard rate is one of the lowest in Europe. This proves the extremely high value of tax preferences applied in Poland with respect to VAT [Adamczyk, 2016, pp. 10-11; Tax Reforms ..., 2015, p. 37]. Until the end of June 2020, according to Polish legal regulations the scope of a specific category in relation to goods was defined by reference to the Polish Classification of Goods and Services (PKWiU 2008) [Rozporządzenie, 2015] or the Polish Classification of Construction Objects (PKOB), or in some situations the descriptive mode was used. For the purposes of

${ }^{3}$ Data for 2018, source: Ministry of Finance. 
import taxation, the Combined Nomenclature $(\mathrm{CN})$ was used, however, at reduced rates. In relation to services, PKWiU 2008 and the descriptive mode were utilised.

The Act of $9^{\text {th }}$ August 2019 amending the VAT Act and certain other acts introduced a new rate matrix ${ }^{4}$. The new matrix introduced a fundamental change to the scope of the reduced rates for goods, however with respect to services it introduced certain modifications compared to the previous position. The entry into force of the new rates matrix has been foreseen in two stages. Since November 2019, new taxation rules have been in force for paper and electronic publications. As of $1^{\text {st }}$ July 2020, the second part of the new rate matrix for other goods and services shall apply. The fundamental change that has taken place in the new matrix of VAT rates for goods is that the scope of reduced rates of taxation of goods is (in principle) linked to the Combined Nomenclature $(\mathrm{CN})$. As previously, services have remained linked to the PKWiU, however, this link has been updated by referring to the PKWiU 2015. In some circumstances, the scope of application of the reduced rate for goods or services has been established descriptively. Two reduced rates have been left at the same level of $5 \%$ and $8 \%$, with their scope of application further extended as compared to the situation before 1st July 2020.

\section{Binding Rate Information in theory}

For entrepreneurs, the application of different VAT rates is an administrative scutwork. Different VAT rates, whether based on the Combined Nomenclature or other criteria, complicate the taxpayer's accounting system and require additional supervision of controls. In addition, they increase the number of settlements with tax refunds, lead to classification problems ${ }^{5}$ and encourage abuse in the classification of goods and services [Tratkiewicz, 2016, p. 603]. An extensive catalogue of tax preferences, especially in the situation of applying several rates with a relatively small difference (e.g. 2, 3 percentage points) and the difficulty in assigning the right rate to a given transaction, distorts the transparency of the tax system and increases compliance costs [Tratkiewicz, 2014, p. 318; Cnossen, 2003, p. 438]. Using more than one rate results in doubling the cost of adjustment. Differentiation of rates is in many cases justified only politically, not economically. Reducing the VAT rate could be considered to be economically justified if there were any convincing arguments that the reduction of the rate shall entail the reduction of the price, however, such relation is not obvious [Bernal, 2019, p. 43, 210].

\footnotetext{
4 This Act of Law introduced a new matrix in two dates; from 1.11.2019, there were new taxation principles with reference to paper and electronic publications, and the remaining part of the matrix was to enter into force on 1.04.2020. However, by the Act of 31.03 .2020 amending the Act on specific solutions related to the prevention, counteracting and eradication of COVID-19, other infectious diseases and crisis situations caused by them, as well as some other Acts, this deadline was postponed until 1.07.2020 (art. 63 of the said Act).

${ }^{5}$ For example, in the case of catering services [Rogowska-Rajda, Tratkiewicz, 2020, p. 13-22].
} 
Since the scope of application of reduced rates in Poland is very broad and the regulations define the scope of application of the appropriate rate by taxpayers to their activities in various ways, the application of reduced rates raises numerous doubts and generates significant tax risks. This issue is important for entrepreneurs due to the VAT prevalence and its price-setting character [Famulska, 2007, p. 154]. Therefore, to minimise this risk, the institution of the Binding Rate Information (WIS) was introduced to the Polish regulations as one of the elements of the socalled new rate matrix. Apart from the institution of individual interpretation, the Binding Excise Information and Binding Tariff Information, This institution, is another tax risk management tool, constituting a normative guarantee of the freedom of information, which eliminates the uncertainty of taxpayers concerning their duties and entitlements, allowing for an accurate planning of future business ventures in relation to the correctness of applied VAT rates [Strategie podatkowe..., 2013, p. 65]. WIS is an indefinite decision issued by the Director of the National Revenue Information System (KIS) for the purposes of VAT taxation of supply, import, intra-Community acquisition of goods or providing services. Taxpayers will be able to use the WIS decision, which refers to the classification of goods according to $\mathrm{CN}$ or $\mathrm{PKOB}$ or $\mathrm{PKWiU}$, or other classifications, also for the purposes of applying VAT regulations referring to the specific classification. The WIS received by a taxpayer shall contain: a description of subject goods or services, and the classification of goods according to $\mathrm{CN}$ or PKOB or of services according to PKWiU 2015 if such classification is necessary to determine the rate. The WIS application may also concern several goods or services which, in the applicant's opinion, constitute one transaction. Individual interpretations shall not be issued within the scope of the Binding Rate Information. Should taxpayers wish to obtain information on the appropriate rate for the sold goods or services, this will only be possible by applying for the WIS.

The WIS will be an instrument of a high protective value and will be binding for the tax authorities with reference to the entity for which it has been issued and for the specific goods or services concerned. This means that the tax authority will not be able to question, for example, the tax rate applied by the taxpayer on the basis of the WIS obtained, provided that, of course, the goods or services sold are identical to the goods or services covered by the WIS (in terms of characteristics and properties). In case of a change or a revocation of the WIS, the taxpayer for whom it has been issued, will be able to apply the WIS issued for him for the period until the end of the settlement period following the settlement period in which the WIS was changed/revoked (a month or a quarter).

The WIS may also be used by entities other than the entity for whom the WIS was issued for the purpose of VAT taxation of their transactions (also, the contracting authorities within the meaning of the Public Procurement Law), provided that the subject of these transactions are goods/services identical in every respect to those that are subject to the WIS. This will be possible in practice on a fairly large scale, e.g. not only the producer receiving the WIS for a given product will be able to inform the purchasers about its settlement, as the WIS will also be published in 
the Public Information Bulletin of the National Revenue Information System (KIS) (after deletion of sensitive data identifying the taxpayer or the ordering party or other entities indicated therein, and also data covered by the company secret). In such a case, i.e. when the WIS is used by another taxpayer, the WIS will also be of a protective nature, identical to the protection provided for a taxpayer using the interpretation of tax regulations issued pursuant to the Tax Ordinance. Similar protection will be available to holders of the Binding Excise Information (WIA) issued under the Excise Duty Act [2008], as well as other taxpayers who make use of such decisions. These decisions determine the correct classification of goods according to the Combined Nomenclature and thus make it easier for a taxpayer to correctly allocate the VAT rate to a given $\mathrm{CN}$ grouping. In the case of the Binding Rate Information, its binding force has not been excluded even in the event of an abuse of law by the recipient with the use of goods or services covered by the WIS, as is the case with individual interpretations.

The WIS application has been formalised. The application form has been introduced by the Regulation of the Minister of Finance, Investment and Development of 29th October 2019 on the application form for Binding Rate Information [Rozporzadzenie, 2019a]. The WIS application is subject to a fee of PLN 40. One application may concern a good or a service. In a situation where the application concerns goods or services which, in the applicant's opinion, together constitute one taxable activity, the fee is determined as a product of the amount of 40 PLN and the number of goods/services constituting together one taxable activity. If in order to examine the WIS application it is necessary to carry out tests or analyses, the applicant shall be obliged to cover such costs. Otherwise, the entity authorised to issue the WIS will leave the WIS application unprocessed. The method of payment of the fees for issuing the WIS and the fees for the conducted tests or analyses of the goods has been specified in the Regulation of the Minister of Finance, Investment and Development [Rozporządzenie, 2019b]. In addition to the procedure provided for in Article 42a-42h of the VAT Act [2004], the provisions of Section IV of the Tax Ordinance [Act, 1997] (with certain exceptions) shall apply accordingly in the processing of the WIS application.

However, the protection of the taxpayer resulting from the issued WIS will not be unlimited in time. The WIS will expire by virtue of law in the event of a change in the VAT regulations which directly relate to the goods or services subject to the WIS, as a result of which the issued WIS will become incorrect, i.e. incompatible with the new regulations (e.g. change in the VAT rate for given goods). In case of irregularities, the WIS may also be changed or revoked by the Head of the National Revenue Administration (KAS). In the case of circumstances specified in the VAT Act, the Director of National Revenue Information System (KIS) will also be able to make the change. However, in the event of initiating such proceedings aiming at the change of the WIS, the Head of the KAS will be each time entitled to take it over in order to continue. 


\section{Binding Rate Information and company finances}

Binding Rate Information is a decision confirming the application of the correct VAT rate by the specific business entity. It also confirms the correct classification for the purposes of applying VAT rules on rates other than those used previously, although this functionality will be rather marginal. From the point of view of the company finances, it is crucial not to set the rate but to ensure that it is correctly applied and that competing companies selling the same goods in the market apply the identical rate.

In economic turnover (B2B), the rates are neutral for businesses, as the price is generally set as 'the net value + applicable VAT rate'. In principle, the VAT paid by business partners will be the tax calculated to be deducted by them. However, businesses supplying goods to consumers do not usually set prices before tax separately, mechanically adding the applicable VAT rate to them. In any competitive consumer market, they must take into account, among other things, the highest level of prices taking into account the value of the tax that the market is able to absorb or the lowest level that will provide them with sufficient turnover to make lower profit margins profitable [Opinia, 2016, items 83-84]. Therefore, when VAT rates increase or decrease, businesses often do not (completely) transfer the impact of such changes onto consumers [Rogowska-Rajda, Tratkiewicz, 2018, p. 143]. The reduction of VAT rates does not generally cause any significant price drops. The reduction is "consumed" by companies, increasing their profit margin. This means that consumers do not benefit from the tax rate reduction. On the other hand, when the VAT rates increase, the reaction of businesses is different. In principle, the rate increase is not fully transferred onto consumers, but its lowest defined range amounts to $33 \%$ of the total additional tax [Bernal, 2019, p. 153].

The richness of economic life and the extensive system of reduced rates in Poland are the reasons for numerous disputes between entrepreneurs and tax authorities with reference to the qualifications of particular goods, in particular food products. Such disputes are often finalized not only in the Provincial or Supreme Administrative Courts [Wyrok WSA, 2019; Wyrok NSA, 2015; Wyrok NSA, 2018], but also in the EU Court of Justice [Wyrok TSUE, 2017; Postanowienie NSA, 2019]. Disputes concerning the level of taxation arise also in the case of classification of complex transactions [Wyrok NSA, 2015]. The difficulty in assigning an appropriate rate to a specific transaction results in high costs related to tax compliance [Tratkiewicz, 2014, p. 318]. Diversity of judicial decisions issued in this respect by tax authorities and administrative courts causes that in practice there are situations when as a result of a final court judgment one company is entitled to apply a reduced rate, while another is not. Since such an entity can offer the lowest price, e.g. in tenders organised under public procurement procedures, there is a significant change in competition conditions.

Until the end of June 2020, entrepreneurs were able to apply for an individual interpretation regarding the application of the VAT rates, however, the responsibility related to the classification of a given good or service remained on their side. The 
interpretation was issued only since the classification provided by the entrepreneurs. In accordance with the methodological principles of statistical classifications, the procedure was that the interested party should classify its activity, its products (goods and services), fixed assets or construction works according to the principles set out in particular classifications and nomenclatures, introduced by a regulation of the Council of Ministers or applied directly on the basis of European Community regulations. Only in the case of difficulties in determining the appropriate grouping, the interested party may apply for an indication to classify the type of their activity, goods or services, fixed assets or construction works to the Centre for Classifications and Nomenclatures of the Statistical Office (OKiNUS) in Lódź [www 1]. However, such opinion was not an administrative decision, nor was it binding. Therefore, such opinions did not guarantee any legal protection to entrepreneurs and in case the above mentioned Centre changed its interpretation, which would mean a change of the VAT rate, it would result in financial consequences. In the event of a change of classification resulting in an increase of the rate, the entrepreneur was obliged to pay the difference in the rate (between the applied reduced rate and the applicable rate) for all past non-prescribed periods increased by any due interests. In extreme cases, the amount of tax arrears could potentially lead to bankruptcy. Alternatively, in the case of a change in the classification resulting in a reduction of the VAT rate, an entrepreneur might have a problem in obtaining a refund of unduly paid tax, which was often related to interpretation disputes concerning unjustified enrichment [Wyrok TSUE, 2008; Opinia, 2007; Uchwała NSA, 2011; Wyrok NSA, 2019]. When companies apply a higher rate than should be applied, they may lose competitiveness. Therefore, any irregularity in the application of the VAT rate has negative consequences for the company's finances.

The introduction of the institution of the Binding Rate Information was the legislator's response to the problems of entrepreneurs described above ${ }^{6}$. Firstly, the WIS provides legal protection for entrepreneurs, by binding the tax authorities with the decisions contained therein concerning the VAT rate. The law allows to change the Binding Rate Information in strictly defined cases, however, such a change has a legal effect acting only "forwards". Binding Rate Information is also open and accessible to all entrepreneurs; after data anonymisation it is placed on the website of the National Revenue Administration.

\section{Binding Rate Information in practice}

The new rate matrix will only become applicable from July 2020, however businesses have been already actively using the possibility to apply for WIS (table 1). From January 2020, the number of WIS applications started to exceed the number of VAT interpretation requests (by 170 applications); in February 2020, there were

\footnotetext{
${ }^{6}$ Similar premises were behind the introduction of the institution of tax interpretations [Famulska, 2013, p. 323].
} 
already 60\% more WIS applications than interpretation requests, and in March it was approximately equal to the total number of all interpretation requests (only 331 fewer WIS applications).

TABLE 1

Number of WIS applications in comparison with the individual interpretation requests, including those VAT-related, in the period from November 2019 to March 2020

\begin{tabular}{|l|c|c|c|c|c|}
\hline \multicolumn{1}{|c|}{ Number } & $\mathbf{1 1 . 2 0 1 9}$ & $\mathbf{1 2 . 2 0 1 9}$ & $\mathbf{0 1 . 2 0 2 0}$ & $\mathbf{0 2 . 2 0 2 0}$ & $\mathbf{0 3 . 2 0 2 0}$ \\
\hline WIS applications & 189 & 677 & 1,033 & 1,767 & 2,029 \\
\hline Interpretation requests & 2,113 & 2,568 & 2,332 & 2,536 & 2,360 \\
\hline including VAT-related & 1,022 & 1,261 & 863 & 1,101 & 1,179 \\
\hline
\end{tabular}

Source: author's own elaboration according to data of National Revenue Information System (KIS) (unpublished data).

After the initial high interest in the classification opinions issued by the Centre for Classifications and Nomenclatures of the Statistical Office (OKiNUS) in Lódź in November (446), the number of applications gradually decreased as the number of WIS applications increased (table 2). The submission of applications to OKiNUS was primarily due to the need to confirm the classification of goods and services for the purposes of applying the split payment mechanism for VAT, which will only be covered by the WIS to some extent as of July [Wiqżqca Informacja..., 2019].

TABLE 2

Number of applications for classification opinions from November 2019 to March 2020

\begin{tabular}{|l|c|c|c|c|c|}
\hline \multicolumn{1}{|c|}{ Number } & $\mathbf{1 1 . 2 0 1 9}$ & $\mathbf{1 2 . 2 0 1 9}$ & $\mathbf{0 1 . 2 0 2 0}$ & $\mathbf{0 2 . 2 0 2 0}$ & $\mathbf{0 3 . 2 0 2 0}$ \\
\hline $\begin{array}{l}\text { Applications for classification } \\
\text { according to PKWiU }\end{array}$ & 446 & 244 & 215 & 166 & 137 \\
\hline $\begin{array}{l}\text { Applications for classification } \\
\text { according to PKOB }\end{array}$ & 6 & 1 & 3 & 6 & 2 \\
\hline
\end{tabular}

Source: author's own elaboration according to data from the Centre for Classifications and Nomenclatures in Lódź (unpublished data)

The majority of submitted applications were received from the Mazowieckie Voivodeship (approx. 40\%) and the Wielkopolskie Voivodeship (approx. 20\%). The Silesian Voivodeship also stands out (ca. 9\%) - table 3. 
TABLE 3

Territorial distribution of WIS applications

\begin{tabular}{|l|c|c|}
\hline \multicolumn{1}{|c|}{ Voivodeship } & No. of applications & Share (in \%) \\
\hline Dolnośląskie & 253 & 4.44 \\
\hline Kujawsko-pomorskie & 153 & 2.69 \\
\hline Lubelskie & 216 & 3.79 \\
\hline Lubuskie & 12 & 0.21 \\
\hline Lódzkie & 249 & 4.37 \\
\hline Małopolskie & 287 & 5.04 \\
\hline Mazowieckie & 2231 & 39.17 \\
\hline Opolskie & 86 & 1.51 \\
\hline Podkarpackie & 73 & 1.28 \\
\hline Podlaskie & 74 & 1.30 \\
\hline Pomorskie & 245 & 4.30 \\
\hline Ślaskie & 477 & 8.38 \\
\hline Świętokrzyskie & 101 & 1.77 \\
\hline Warmińsko-mazurskie & 35 & 0.61 \\
\hline Wielkopolskie & 1069 & 18.77 \\
\hline Zachodnio-pomorskie & 62 & 1.09 \\
\hline other (abroad) & 72 & 1.26 \\
\hline
\end{tabular}

Source: author's own elaboration according to data of National Revenue Information System (KIS) (unpublished data).

After the initial "start-up" period of the institution's activity, the number of applications dealt with by the National Revenue Information System (KIS) has been growing from month to month, although in the initial period other decisions (not related to VAT classification) prevailed (table 4). The main reason for issuing such decisions is incorrect filling in of applications and applying for the WIS with regard to the legal status valid until the end of June 2020. (i.e. the "old rate matrix"), despite detailed guidelines in this respect published on the National Revenue Information System website [www 2].

TABLE 4

Number of issued WIS and other decisions from 11.2019 to 03.2020

\begin{tabular}{|l|c|c|c|c|c|}
\hline \multicolumn{1}{|c|}{ Number } & $\mathbf{1 1 . 2 0 1 9}$ & $\mathbf{1 2 . 2 0 1 9}$ & $\mathbf{0 1 . 2 0 2 0}$ & $\mathbf{0 2 . 2 0 2 0}$ & $\mathbf{0 3 . 2 0 2 0}$ \\
\hline WIS & 0 & 0 & 15 & 474 & 413 \\
\hline Other decisions & 0 & 6 & 62 & 229 & 369 \\
\hline Total & 0 & 6 & 77 & 703 & 782 \\
\hline
\end{tabular}

Source: author's own elaboration according to data of National Revenue Information System (KIS) (unpublished data). 
The fundamental change in the way goods are identified in the new rate matrix, based on the $\mathrm{CN}$, clearly translates into the number of enquiries from the applicants. In the submitted applications, the majority of enquiries are about the classification of goods in the $\mathrm{CN}$ (over 90\%). Despite difficulties in classifying complex transaction, there are few applications in this area, and they constitute less than $4 \%$ of all applications (table 5). Therefore, the structure of the subject matter of the applications shows that the questions are dominated by issues related to the change of regulations concerning the new rate matrix, rather than the previously existing problems in applying VAT rates.

\section{TABLE 5}

\section{Structure of the subject matter of applications}

\begin{tabular}{|l|c|c|}
\hline \multicolumn{1}{|c|}{ Scope of applications } & Number of applications & Share (\%) \\
\hline Goods & 5149 & 90.41 \\
\hline Services & 329 & 5.78 \\
\hline Complex transactions & 217 & 3.81 \\
\hline Total & 5695 & 100.00 \\
\hline
\end{tabular}

Source: author's own elaboration according to data of National Revenue Information System (KIS) (unpublished data).

\section{Conclusions}

The institution of the Binding Rate Information undoubtedly provides a support for companies, reducing the tax risk associated with the application of VAT rates and related business activities, thus reducing the financial costs of their operations. For this reason, entrepreneurs willingly use this institution. However, this institution may be the cause of disturbing the competitiveness of enterprises on the market in case of discrepancies in judicial decisions issued with respect to rate information. Therefore, it is crucial to maintain uniformity in decisions made by the National Revenue Information System (KIS). Due to the short duration of the WIS, a comprehensive assessment of its impact on the finances of enterprises will only be possible in the future. The initial assessment from the perspective of a period of less than six months is positive, however there is a need to set the Binding Rate Information within a specific timeframe. This will ensure that the decisions are up to date and can be applied with certainty. Moreover, from the point of view of ensuring full competitiveness of enterprises, it is necessary to exclude the protective power of the WIS in cases where goods or services covered by such a decision are elements of a artificial constructs which are in fact violations of law. Furthermore, it should be also considered whether VAT exemptions should also be covered by the Binding Rate Information to (binding exemption information). 


\section{References}

Act, 1997, Ustawa z dnia 29 sierpnia 1997 r. - Ordynacja podatkowa, Dz. U. z 2019 r. poz. 900 , z późn. zm.

Act, 2004, Ustawa z dnia 11 marca 2004 r. o podatku od towarów i usług, Dz. U. z 2020 r., poz. 106.

Act, 2008, Ustawa z dnia 6 grudnia 2008 r. o podatku akcyzowym, Dz. U. z 2020 r. poz. 722.

Act, 2019, Ustawa z dnia 9 sierpnia 2019 r. o zmianie ustawy o podatku od towarów i usług oraz niektórych innych ustaw, Dz. U. poz. 1751, z późn. zm.

Act, 2020, Ustawa z dnia 31 marca 2020 r. o zmianie ustawy o szczególnych rozwiązaniach zwiazzanych $z$ zapobieganiem, przeciwdziałaniem i zwalczaniem COVID-19, innych chorób zakaźnych oraz wywołanych nimi sytuacji kryzysowych oraz niektórych innych ustaw, Dz. U. poz. 568.

Adamczyk A., 2016, Ocena proposycji zmian w polskim podatku od wartości dodanej, „Studia Ekonomiczne. Uniwersytet Ekonomiczny w Katowicach", nr 273, s. 7-18.

Bernal A., 2019, Podatek od wartości dodanej. Studium przerzucalności podatku na konsumentów, pracownikón $i$ dawcón kapitalu, Wydawnictwo Uniwersytetu Ekonomicznego w Poznaniu, Poznań.

Cnossen S., 2003, Is the VAT's Sixth Directive Becoming an Anachronism?, „European Taxation", pp. 434-442.

Dyrektywa, 2006, Dyrektywa 2006/112/WE Rady z dnia 28 listopada 2006 r. w sprawie wspólnego systemu podatku od wartości dodanej, Dz. Urz. UE L 347 z 11.12.2006 r., s. 1, z późn. zm.

Famulska T., 2007, Teoretyczne i praktyczne aspekty funkcjonowania podatku od wartości dodanej, Wydawnictwo Akademii Ekonomicznej w Katowicach, Katowice.

Famulska T., 2013, Oddziaływanie instytucji interpretacji podatkowych na finanse przedsiębiorstw, Difin, Warszawa.

Opinia, 2007, Opinia Rzecznika Generalnego z dnia 13 grudnia 2007 r. w sprawie C-309/06, Marks \& Spencer, ECLI:EU:C:2007:785.

Opinia, 2016, Opinia Rzecznika Generalnego z dnia 10 marca 2016 r. w sprawie C-543/14, Ordre des barreaux francophones et germanophone e.a. $\mathrm{i}$ in. przeciwko Conseil des ministres, ECLI:EU:C:2016:157.

Postanowienie NSA, 2019, Postanowienie NSA z dnia 6 czerwca 2019 r., sygn. akt I FSK 1290/18.

Rogowska-Rajda B., Tratkiewicz T., 2018, Cay barmonizacja stawek. VAT w Unii Europejskiej jest jeszcze konieczna?, „Myśl Ekonomiczna i Polityczna”, nr 1(60), s. 136-154, DOI: 10.26399/meip.1(60).2018.05/b.rogowska-rajda,t.tratkiewicz.

Rogowska-Rajda B., Tratkiewicz T., 2020, Gastronomia w nowej matrycy stawek, „Przegląd Podatkowy" nr 5.

Rozporządzenie, 2015, Rozporządzenie Rady Ministrów z dnia 4 września 2015 r. w sprawie Polskiej Klasyfikacji Wyrobów i Usług (PKWiU), Dz. U. poz. 1676, z późn. zm. 
Rozporządzenie, 2019a, Rozporządzenie Ministra Finansów, Inwestycji i Rozwoju z dnia 29 października 2019 r. w sprawie wzoru wniosku o wydanie wiążącej informacji stawkowej, Dz. U. poz. 2109.

Rozporządzenie, 2019b, Rozporządzenie Ministra Finansów, Inwestycji i Rozwoju z dnia 3 października 2019 r. w sprawie sposobu uiszczenia opłat dotyczących wydania WIS, Dz. U. poz. 1945.

Strategie podatkowe przedsiebiorstw, 2013, Ciupek B., Famulska T. (red.), Wydawnictwo Uniwersytetu Ekonomicznego w Katowicach, Katowice.

Tax Reforms in EU Member States. Tax policy challenges for economic growth and fiscal sustainability, 2015, "Institutional Paper" 008.

Tratkiewicz T., 2014, Podatek od towarów i uslug jako narzedzie polityki fiskalnej w latach 2004-2013, „Studia Ekonomiczne. Uniwersytet Ekonomiczny w Katowicach”, nr 198, s. 307-322.

Tratkiewicz T., 2016, W kierunku jednej stawki VAT - korzyśsi i nyzwania na prazyktadrie Polski, „Annales Universitatis Mariae Curie-Składowska”, vol. 50(1), s. 601610, DOI: 10.17951/h.2016.50.1.601.

Uchwała NSA, 2011, Uchwała NSA z dnia 22 czerwca 2011 r., sygn. akt I GPS 1/11.

Wiażaca Informacja Stawkowa (WIS) - okeres przejściony, 2019, Komunikat Ministerstwa Finansów z dnia 28 października 2019 r..

Wyrok NSA, 2008, Wyrok TSUE z dnia 10 kwietnia 2008 r. w sprawie C-309/06, Marks \& Spencer, ECLI:EU:C:2008:211.

Wyrok NSA, 2015a, Wyrok NSA z dnia 6 maja 2015 r. sygn. akt I FSK 854/14.

Wyrok NSA, 2015b, Wyrok NSA z dnia 3 lipca 2015 r. sygn. akt I FSK 854/14.

Wyrok NSA, 2018, Wyrok NSA z dnia 5 kwietnia 2018 r., sygn. akt I FSK 1853/17.

Wyrok NSA, 2019, Wyrok NSA z dnia 17 czerwca 2019 r. sygn. akt I FSK 912/17.

Wyrok TSUE, 2017, Wyrok TSUE z dnia 9 listopada 2017 r. w sprawie C-499/16 AZ, ECLI:EU:C:2017:846.

Wyrok WSA, 2019, Wyrok WSA we Wrocławiu z dnia 17 maja 2019 r., sygn. akt I SA/Wr 58/19.

www 1, https://lodz.stat.gov.pl/osrodki/osrodek-klasyfikacji-i-nomenklatur-urzedu -statystycznego-w-lodzi/ [date of entry: 5.05.2020].

www 2, https://www.kis.gov.pl/zalatwianie-spraw/wiazaca-informacja-stawkowawis [date of entry: 5.05.2020]. 